\title{
Anesthetic potential of different essential oils for two shrimp species, Farfantepenaeus paulensis and Litopenaeus vannamei (Decapoda, Crustacea)
}

\author{
Alessandra Janaína Becker ${ }^{1}$ Luciano Jensen $\operatorname{Vaz}^{2}$ (D) Luciano de Oliveira Garcia ${ }^{3}$ (iD \\ Wilson Wasielesky $\mathbf{J r}^{3}$ (D) Berta Maria Heinzmann ${ }^{4}$ (D) Bernardo Baldisserotto ${ }^{1,5^{*}}$ (D)
}

\footnotetext{
${ }^{1}$ Departamento de Fisiologia e Farmacologia, Universidade Federal de Santa Maria (UFSM), 97105-900, Santa Maria, RS, Brasil. E-mail: bbaldisserotto@hotmail.com. "Corresponding author.

${ }^{2}$ Instituto de Ciências e Tecnologia das Águas, Universidade Federal do Oeste do Pará (UFOPA), Santarém, PA, Brasil.

${ }^{3}$ Instituto de Oceanografia, Estação Marinha de Aquicultura, Universidade Federal do Rio Grande (FURG), Rio Grande, RS, Brasil. ${ }^{4}$ Departamento de Farmácia Industrial, Universidade Federal de Santa Maria (UFSM), Santa Maria, RS, Brasil.

${ }^{5}$ Programa de pós-graduação em Zootecnia Universidade Federal de Santa Maria (UFSM), 97105-900, Santa Maria, RS, Brasil.
}

ABSTRACT: The use of anesthetics in aquaculture ensures better animal welfare and survival during transport and the production cycle. The present study evaluated the anesthetic efficacy of essential oils (EOs) of Lippia alba (EOLA) and Ocimum gratissimum (EOOG) for pink shrimp Farfantepenaeus paulensis, and EOs of Origanum majorana (EOO) and Cymbopogon citratus (EOC) for white shrimp Litopenaeus vannamei. shrimp were exposed to (i) 500, 750 or $1000 \mu \mathrm{L} \mathrm{L}^{-1}$ of EOLA or (ii) 50,100, 150 or $250 \mu \mathrm{L} \mathrm{L} \mathrm{L}^{-1}$ of EOOG, and L. vannamei were

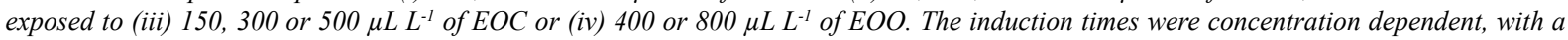
decrease in induction time with the increase of the EOs concentration, but for EOLA, this pattern was observed only for anesthesia. Induction times for sedation and anesthesia were significantly shorter for shrimp exposed to EOC and EOO. The highest concentration of EOOG (250 $\left.\mu L L^{-1}\right)$ resulted in $30 \%$ mortality. The recovery time was significantly longer for shrimp exposed to $800 \mu L L^{-1}$ of EOO compared to the other EOs. Overall, the action of EOs significantly differed between the two shrimp species. In conclusion, the tested EOs effectively anesthetized $F$. paulensis and L. vannamei.

Key words: anesthesia; crustacean; handling; sedation; natural products.

Potencial anestésico de diferentes óleos essenciais para duas espécies de camarões, Farfantepenaeus paulensis e Litopenaeus vannamei (Decapoda, Crustacea)

RESUMO: $O$ uso de anestésicos em procedimentos aquicolas pode garantir melhor bem-estar e sobrevivência dos animais durante o transporte e ciclo de produção. O presente estudo teve como objetivo avaliar a eficácia anestésica dos óleos essenciais (OEs) de Lippia alba (EOLA) e Ocimum gratissimum (EOOG) para o camarão rosa Farfantepenaeus paulensis, e Origanum majorana (EOO) e Cymbopogon citratus (EOC) para o camarão branco Litopenaeus vannamei. Os camarões foram expostos à: (i) 500 , 750 ou $1000 \mu L L^{-1}$ EOLA e (ii) 50, 100, 150 ou $250 \mu L_{L^{-1}}$ de EOOG para F. paulensis, e (iii) 150, 300 ou $500 \mu L_{L}^{-1}$ EOC, e (iv) 400 ou $800 \mu L L^{-1}$ de EOO para L. vannamei. Os tempos de indução foram dependentes da concentração. Houve diminuição do tempo de indução, mas para EOLA esse padrão foi observado apenas na anestesia. Os tempos de indução para sedação e anestesia foram significativamente mais rápidos para os grupos EOC e EOO. A concentração de $250 \mu \mathrm{L} \mathrm{L} \mathrm{L}^{-1}$ de EOOG resultou em $30 \%$ de mortalidade. O tempo de recuperação foi significativamente maior a $800 \mu \mathrm{L} \mathrm{L}^{-1}$ de EOO em comparação aos outros OEs. No geral, a ação dos OEs foi significativamente diferente entre as duas espécies de camarões. Em conclusão, ambos os OEs anestesiaram efetivamente o F. paulensis e L. vannamei.

Palavras-chave: anestesia; crustáceos; manejo; sedação; produtos naturais; bem-estar.

\section{INTRODUCTION}

Shrimp represent the main group of farmed crustaceans (FAO, 2020). However, the intensification of shrimp farming faces various challenges, such as the increased spread of disease due to incorrect management, which may result in stress and injury (LIGHTNER, 2011). These events lead to the overuse of a variety of antibiotics and antimicrobials, which can accumulate in the cultured shrimp and negatively affect the aquatic environment (ALDERMAN et al., 1998). Stressful conditions are known to alter the behavior and physiology of crustaceans, compromising their immunity and producing damage at the cellular level (MERCIER et al., 2006). Anesthetics are used in shrimp farming to facilitate handling during certain practices, such as weighing, measuring, tagging, eye ablation, collection of tissue samples and transportation of post-larvae or adults 
to spawning sites or cultured ponds (TAYLOR et al., 2004; AKBARI et al., 2010). Essential oils (EOs) are natural compounds derived from secondary plant metabolites, some of which exhibit sedative and anesthetic properties (SOUZA et al., 2019). Furthermore, because they are natural products, the application of EOs may be more environmentally friendly and cost-effective (REVERTER et al., 2014). Essential oils have been demonstrated to be safe and effective in studies on Litopenaeus vannamei (PARODI et al., 2012), Macrobrachium rosenbergii (SAYDMOHAMED \& PAL, 2009), Palaemonetes sinensis (LI et al., 2018a) and Penaeus monodon (JIANG et al., 2020).

The Pacific white shrimp, L. vannamei, is distributed along the Pacific coast from western Mexico to northern Peru and is considered one of the primary shrimp species produced worldwide (FAO, 2020). In contrast, Farfantepenaeus paulensis, known as pink shrimp, is a native marine species distributed from Ilhéus (Brazil) to Mar del Plata (Argentina), which is considered an alternative species for aquaculture in southern and southeastern Brazil (PRETO et al., 2009). To our knowledge, the effect of EOs on pink shrimp has not yet been investigated. Previous studies have demonstrated an anesthetic effect of the EO of Lippia alba (EOLA) on L. vannamei shrimp (PARODI et al., 2012). Therefore, this study evaluated the potential anesthetic effects of different EOs on two species of penaeid shrimp. We compared the anesthetic and sedative efficacy of EOLA and the EO of Ocimum gratissimum (EOOG) on pink shrimp (F. paulensis), as well as the efficacy of the EOs of Origanum majorana (EOO) and Cymbopogon citratus (EOC) on white shrimp (L. vannamei).

\section{MATERIALS AND METHODS}

Shrimp collection, maintenance and water quality analyses

Farfantepenaeus paulensis $(5.96 \pm 0.13$ $\mathrm{g}, 9.18 \pm 0.32 \mathrm{~cm})$ and L. vannamei $(22.6 \pm 1.2 \mathrm{~g}$, $21.7 \pm 0.3 \mathrm{~cm}$ ) shrimp were obtained from the Marine Station of Aquaculture, Universidade Federal do Rio Grande (FURG), Southern Brazil. The animals were maintained in continuously aerated $250-\mathrm{L}$ tanks filled with seawater, with controlled water parameters. Water temperature $\left(22.1 \pm 0.02{ }^{\circ} \mathrm{C}\right)$ was measured using a mercury thermometer (precision $\left.\pm 0.5{ }^{\circ} \mathrm{C}\right)$ and dissolved oxygen $(6.14 \pm 0.01 \mathrm{mg}$ $\mathrm{L}^{-1}$ ) with a YSI oxygen meter (Handylab/OXI/set; Schott $^{\circledR}$, Cambridge, UK). Salinity $(28.0 \pm 0.2 \mathrm{ppt})$ was measured with an optical refractometer (RTS 101; Atago ${ }^{\circledR}$ US, Bellevue, WA, USA) and $\mathrm{pH}$ (7.97 \pm 0.03 ) with digital $\mathrm{pH}$ meter (Handylab $2 \mathrm{BNC}$; Schott $^{\circledR}$, Mainz, Germany). The alkalinity (146.2 $\pm 5.8 \mathrm{mg} \mathrm{CaCO}_{3} \mathrm{~L}^{-1}$ ) was determined according to BAUMGARTEN et al. (1996), and total ammonia nitrogen (TAN) levels $\left(0.13 \pm 0.01 \mathrm{mg} \mathrm{L}^{-1}\right)$ were calculated using the method published by UNESCO (1983).

\section{Plant material and essential oil analysis}

The EOs were obtained by steam distillation in a Clevenger apparatus according to the guidelines of the European Pharmacopoeia (2010). The extraction was performed for $2 \mathrm{~h}$ for EOLA and $3 \mathrm{~h}$ for EOOG. The samples were stored in amber glass vials at $-4{ }^{\circ} \mathrm{C}$. Essential oil analyses were carried out using gas chromatography coupled to mass spectrometry, according to SILVA et al. (2012). The EOs of $C$. citratus (EOC) and $O$. majorana (EOO) were purchased from Vimontti São Caetano Agroindustry (Santa Maria, Rio Grande do Sul, Brazil). The major components identified for EOLA were linalool (58.37\%), 1,8-cineole (6.33\%), germacrene $\mathrm{D}(4.47 \%)$ and $\beta$-caryophyllene (3.64\%). The major compounds of EOOG were eugenol (73.6\%), $\beta$-bisabolene (18.3\%), $\beta$-caryophyllene oxide $(4.8 \%)$ and spathulenol $(1.4 \%)$. The EOC was mainly composed of citral $(74.56 \%)$, mircene (11.85\%) geraniol $(3.08 \%)$, pulegone $(2.37 \%)$ and linalool $(1.56 \%)$, and EOO contained terpinen-4ol $(20.44 \%)$, cis-terpinene, $(13.14 \%)$, cis-terpineol (12.67\%), 2-carene (7.67\%) and sabinene (6.96\%).

\section{Experimental design}

Shrimp were randomly divided into groups and placed in 1-L aquaria for the evaluation of anesthetic activity. Each shrimp was assessed individually and used only once in each replicate at a defined concentration $(n=10$ animals per concentration and per anesthetic). Shrimp were exposed to EOs at the following concentrations: (i) 500,750 or $1000 \mu \mathrm{L} \mathrm{L}^{-1}$ of EOLA or (ii) 50, 100, 150 , or $250 \mu \mathrm{L} \mathrm{L}^{-1}$ of EOOG for $F$. paulensis; and (iii) 150,300 or $500 \mu \mathrm{L} \mathrm{L}^{-1}$ of EOC or (iv) 400 or $800 \mu \mathrm{L} \mathrm{L}^{-1}$ of EOO for L. vannamei. After exposure to the EOs, animals were transferred to anestheticfree aquaria to determine their recovery time. EOs were dissolved in $100 \%$ ethanol (1:10). Shrimp of both species were exposed to the control treatment, i.e., aquaria containing anesthetic-free seawater. In addition, shrimp of both species were exposed to ethanol at the highest concentration used to dilute 
the EOs (9000 and $7200 \mu \mathrm{L} \mathrm{L}^{-1}$ for $F$. paulensis and $L$. vannamei, respectively). The concentrations of EOs chosen for the biological assays were based on studies by PARODI et al. (2012) and SILVA et al. (2012). Furthermore, the behavioral patterns used to determine the induction time of sedation and anesthesia, as well as the recovery time from anesthesia, were based on descriptions by PARODI et al. (2012) (Table 1). The shrimp were considered recovered when they regained their balance and were able to maintain a vertical position in the aquarium. The maximum observation time to evaluate sedation or anesthesia and the recovery time was $30 \mathrm{~min}$. The response to external stimuli was through the use of a glass rod. Light touches were made on the shrimp's abdomen during the loss of balance or reduced swimming. Sedated shrimp presented a normal escape response to tactile stimuli, and anesthetized shrimp did not react to tactile stimuli.

\section{Statistical analyses}

Data were expressed as mean \pm SEM. The homogeneity of variance between groups was tested with Levene's test. Anesthetic activity was evaluated by regression analysis (concentration vs. time of anesthesia induction; concentration vs. time of recovery from anesthesia) using Sigma Plot 11.0 software. If no relationship was present, a comparison of the effects of different EO concentrations on anesthesia and recovery times was performed using one-way ANOVA followed by Tukey's test. Analyses were performed using STATISTICA software (version 7.0, StatSoft, Tulsa, OK, USA), with the minimum significance level set at $\mathrm{P}<0.05$.

\section{RESULTS}

As the concentrations of EOLA and EOOG increased, the time required for the induction of sedation and anesthesia in pink shrimp decreased. However, for both EOs, the recovery times did not significantly differ between the different concentrations. The time required inducing the sedation and anesthesia with EOLA at $1000 \mu \mathrm{LL}^{-1}$ was shorter than that for 500 and $750 \mu \mathrm{L} \mathrm{L}^{-1} \mathrm{EOLA}$ (Figure 1A). Most shrimp exposed to $50 \mu \mathrm{L} \mathrm{L}^{-1}$ EOOG were not anesthetized within the 30 -min evaluation period, while others showed signs of anesthesia close to the maximum time. There were no significant differences to sedation and anesthesia induction between 100 and $150 \mu \mathrm{L} \mathrm{L}^{-1}$ concentrations of EOOG, which induced anesthesia within about $10 \mathrm{~min}$. At a concentration of $250 \mu \mathrm{L} \mathrm{L}^{-1}$, EOOG quickly induced anesthesia (Figure 1B) but caused $30.0 \pm 1.5 \%$ mortality. The recovery time was significantly longer for shrimp anesthetized with EOLA than with EOOG.

There were no differences in the time required to induce sedation and anesthesia stages between 150 and $300 \mu \mathrm{L} \mathrm{L}^{-1}$ of EOC. The EOC concentration of $500 \mu \mathrm{L} \mathrm{L}^{-1}$ presented the shortest time to induce sedation and anesthesia stages. Recovery from anesthesia was significantly longer when shrimp were exposed to 300 and $500 \mu \mathrm{L} \mathrm{L}^{-1}$ of EOC (Figure 1C). The lowest concentrations of $\mathrm{EOO}(50,100$ and $200 \mu \mathrm{L} \mathrm{L}^{-1}$ ) failed to induce sedative or anesthetic effects, whereas the highest concentrations (400 and $800 \mu \mathrm{L} \mathrm{L}^{-1}$ ) produced sedation and anesthesia in white shrimp. There were no significant differences in the anesthesia induction between 400 and $800 \mu \mathrm{L} \mathrm{L}^{-1}$ EOO. However, the recovery time was significantly longer in shrimp exposed to $800 \mu \mathrm{L} \mathrm{L}^{-1} \mathrm{EOO}$ (Figure 1D). Exposure to EOC or EOO presented the shortest times for the induction of anesthesia. Ethanol did not induce sedation or anesthesia in either of the shrimp species tested.

\section{DISCUSSION}

Essential oils exhibit various compositions which are dependent on several factors, such as plantspecific genetic characteristics (chemotype), local conditions and extraction methods (EDRIS, 2007).

Table 1 - Stages of anesthesia induction and recovery used for Litopenaeus vannamei in this study (adapted from Parodi et al. 2012).

\begin{tabular}{lcr}
\hline Stage & Description & Behavioural Response \\
\hline 1 & Sedation & Partial loss of balance and presence of response to external stimuli \\
2 & Anesthesia & Total loss of balance, but no response to external stimuli \\
3 & Recovery & The shrimps were considered recovered when they returned the normal posture, behavior and swimming in \\
& & the aquaria. \\
\hline
\end{tabular}

Ciência Rural, v.51, n.12, 2021. 


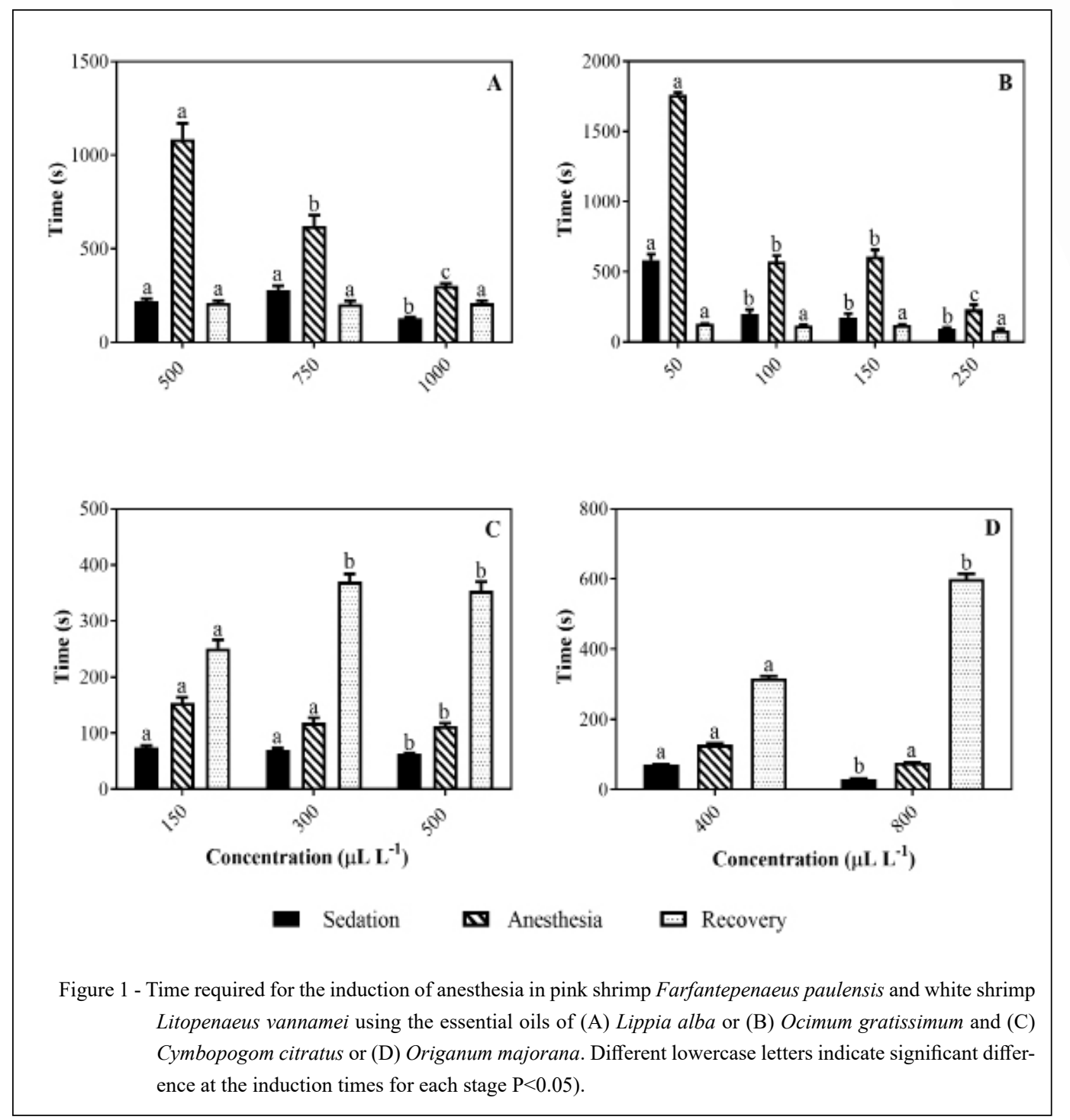

In the present study, chromatographic analysis identified linalool, eugenol, citral and terpinen4-ol as the major constituents of EOLA, EOOG, EOC and EOO, respectively. These isolated compounds have demonstrated anesthetic activity in several crustaceans, including $L$. vannamei, $M$. rosenbergii, $P$. sinensis, Neohelice granulata and Nephrops norvegicus (PARODI et al., 2012; COWING et al., 2015; LI et al., 2018b; SOUZA et al., 2018).

In the current study, we reported that the concentration of EOLA directly influenced the time required to induce anesthesia in $F$. paulensis. Similar responses were observed in L. vannamei anesthetized with either eugenol or Aloysia triphylla (PARODI et al., 2012). Additionally, the anesthesia induction and recovery times of $F$. paulensis exposed to EOLA in our study were faster than those reported by PARODI et al. (2012) for L vannamei. This may be explained by differences in the body size of the shrimp species, as the body weight of pink shrimp is 3 -fold lower than white shrimp. Smaller shrimp have higher rate of anesthetic absorption due to the greater gill surface area in relation to body size (BOWNIK, 2015). Studies on $P$. sinensis anesthetized with menthol demonstrated a direct relationship between body size and sensitivity to anesthesia (LI et al., 2018a). However, pink shrimp are likely to be more sensitive to EOLA anesthesia than $L$. 
vannamei because even the post-larvae forms take a longer time to reach anesthesia (PARODI et al., 2012).

Pink shrimp exposed to $250 \mu \mathrm{L} \mathrm{L}^{-1}$ of EOOG presented muscle spasms, escape responses and mortality. Similar results were reported for $M$. rosenbergii exposed to quinaldine and Aqui- $\mathrm{S}^{\mathrm{TM}}$ (COYLE et al., 2005). These side effects occur due to inhibition of the enzyme acetylcholinesterase (AchE) in response to the accumulation of acetylcholine in muscle, which causes excessive muscular stimulation and hyperactivity (NILSSON et al., 1990). However, AchE activity was unchanged in $M$. rosenbergii anesthetized with an anesthetic mixture of menthol and eugenol (SAYDMOHAMED \& PAL, 2009). Therefore, the inhibition of this enzyme is not likely to be responsible for behavioral variations. Thus, further studies are needed to investigate the possible toxic effects of EOOG, especially on metabolic parameters in F. paulensis.

The rationale behind the addition of EOs to water is to induce calming effects in shrimp, with rapid induction (within 3-5 min) and recovery times (10 min or less), without causing harm to the animals (SOUZA et al., 2019). Anesthesia was achieved with EOC within the established time frame, but EOO only induced anesthesia at the highest concentrations. Exposure of L. vannamei to 500 and $1000 \mu \mathrm{L} \mathrm{L}^{-1}$ of EOLA led to anesthesia within 30 and $10 \mathrm{~min}$, respectively (PARODI et al., 2012). Macrobrachium tenellum prawns required 17 and $8 \mathrm{~min}$, respectively, to reach deep anesthesia at clove oil concentrations of 300 and $900 \mu L_{L}^{-1}$ (PALOMERA et al., 2016). Finally, the use of 300 and $900 \mu \mathrm{L} \mathrm{L}^{-1}$ of eugenol induced full anesthesia in $N$. norvegicus in 14 and $4 \mathrm{~min}$, respectively (COWING et al., 2015). Furthermore, increasing concentrations of EOC proportionally decreased anesthesia induction times for two ornamental fish species, Sciaenochromis fryeri and Labidochromis caeruleus (KIZAK et al., 2018).

Anesthesia in shrimp does not induce total immobility as the pleopods and antennae remain in continuous but reduced movement. The movement of pleopods is associated with the entry of water into the branchial chamber towards the scaphognathite. Consequently, the total loss of activity of the motor appendages would impair the respiratory and osmoregulatory processes (HENRY et al., 2012). In this research, there was no relationship between concentration and recovery time for EOLA and EOOG. In contrast, increased EOLA concentrations have previously been reported to decrease the recovery time of L. vannamei (PARODI et al., 2012). Conversely, the time taken by white shrimp to recover from anesthesia increases as the anesthetic concentration increases for EOC and EOO, as observed in the current study. Additionally, the recovery time of $M$. rosenbergii exposed to 100 and $800 \mu \mathrm{L} \mathrm{L}^{-1}$ of eugenol was 17.6 and 55 min, respectively (SAYDMOHAMED \& PAL, 2009), and recovery of Litopenaeus schimitti and Farfantepenaeus brasiliensis from anesthesia with mint oil (Mentha piperita) was longer than $10 \mathrm{~min}$ (MATULOVIC \& OSHIRO, 2016).

The action of EOs significantly differed between the two shrimp species. Shorter induction times were observed for both EOC and EOO when compared to EOLA or EOOG. In addition, the recovery times of $L$. vannamei were longer than those of F. paulensis. Shrimp show behavioral and physiological variations resulting from biological factors such as species, stage of life, sex, body size and lipid content, and environmental factors such as temperature or salinity may significantly affect the action of the anesthetic (LI et al., 2018a,b; JIANG et al., 2020). The metabolism and excretion of anesthetics, which are also influenced by the factors described above, may influence the quality of shrimp for consumption. Eugenol residues were undetectable in $M$. rosenbergii tissues within $24 \mathrm{~h}$ of exposure (SAYDMOHAMMED et al., 2009). Regarding the other main compounds of the EOs tested in the current study, no studies have assessed the elimination of these compounds in crustaceans; however, linalool could not be detected in tissues of the silver catfish Rhamdia quelen after $24 \mathrm{~h}$ (BIANCHINI et al., 2020). Consequently, these studies indicate that a withdrawal time of a few days may be required before human consumption of shrimp anesthetized with these EOs. Additional studies must be performed to confirm this hypothesis.

\section{CONCLUSION}

In conclusion, all EOs showed anesthetic effects in the tested shrimp species. The results suggested that concentrations of $750 \mu \mathrm{L} \mathrm{L}^{-1}$ of EOLA and $100 \mu \mathrm{L} \mathrm{L}^{-1}$ of EOOG may be indicated for $F$. paulensis, while 150,300 or $500 \mu \mathrm{L} \mathrm{L}^{-1}$ of EOC and $200 \mu \mathrm{L} \mathrm{L}^{-1}$ of EOO can be considered effective for $L$. vannamei. Thus, these EOs are indicated for use in procedures that require a prolonged anesthesia time and to avoid stress during handling of the crustaceans.

\section{ACKNOWLEDGEMENTS}

This study was supported by research funds from Ministério da Pesca e Aquicultura, Ministério da Ciência e Tecnologia/FINEP 01.02.0130.00, Fundação de Amparo à Pesquisa 
do Estado do Rio Grande do Sul (FAPERGS) and Coordenação de Aperfeiçoamento de Pessoal de Nível Superior (CAPES), Brasil Finance code 001.

\section{DECLARATION OF CONFLICT OF INTERESTS}

The authors declare no conflicts of interest. The founding sponsors had no role in the design of the study; in the collection, analyses or interpretation of data; in the writing of the manuscript; or in the decision to publish the results.

\section{AUTHORS' CONTRIBUTIONS}

All authors contributed equally to the conception and writing of the manuscript. All authors critically revised the manuscript and approved the final version.

\section{REFERENCES}

AKBARI, S. et al. The use of eugenol as an anesthetic in transportation of with Indian shrimp (Fenneropenaeus indicus) post larvae. Turkish Journal of Fisheries and Aquatic Sciences, v. 10, n. 3, p. 423-429, 2010. Available from: <https://doi.org/10.4194/trjfas.2010.0317>. Accessed: Jun. 22, 2020. doi: 10.4194/trjfas.2010.0317.

ALDERMAN, D. J; HASTINGS, T. S. Antibiotic use in aquaculture: development of antibiotic resistance-potential for consumer health risks. International Journal of Food Science \& Technology, v.33, n. 2, p. 139-155, 1998. Available from: <https:// doi.org/10.1046/j.1365-2621.1998.3320139.x>. Accessed: Jun. 22, 2020. doi: 10.1046/j.1365-2621.1998.3320139.x.

BAUMGARTEN, M.G Z. et al. Manual de análises em oceanografia química. Editora da FURG: Rio Grande, Brazil. 1996. 132p.

BIANCHINI, A.E. et al. Tissue distribution and elimination of S-(+)-linalool in silver catfish (Rhamdia quelen). Aquaculture, v.529, p.735637, 2020. Available from: <https://doi:10.1016/j. aquaculture.2020.735637>. Accessed: Feb. 15, 2020. doi: 10.1016/j.aquaculture. 2020.735637 .

BOWNIK A. 2015. Clove essential oil from Eugenia caryophyllus induces anesthesia, alters swimming performance, heart functioning and decreases survival rate during recovery of Daphnia magna. Turkish Journal of Fisheries and Aquatic Sciences, v. 15, n. 1, p. 157-166, 2015. Available from: <htpps:// doi.org/10.4194/1303-2712-v15 1 17>. Accessed: Jun. 22, 2020. doi: 10.4194/1303-2712-v15_1_17.

COYLE, S.D. et al. Comparative efficacy of anesthetics for the freshwater prawn Macrobrachium rosenbergii. Journal of the World Aquaculture Society, v. 36, n. 3, p. 282-290, 2005. Available from: <https://doi.org/10.1111/j.1749-7345.2005. tb00332.x>. Accessed: Jun. 22, 2020. doi: 10.1111/j.17497345.2005.tb00332.x.

COWING, D. et al. Evaluation of different concentration doses of eugenol on the behaviour of Nephrops norvegicus. Aquaculture, v. 442, p. 78-85, 2015. Available from: <https://doi.org/10.1016/j. aquaculture.2015.02.039>. Accessed: Jun. 22, 2020. doi: 10.1016/j. aquaculture.2015.02.039.
EDRIS, A.E. Pharmaceutical and therapeutic potentials of essential oils and their individual volatile constituents: a review. Phytotherapy Research, v. 21, n. 4, p. 308-323, 2007. Available from: <https://doi.org/10.1002/ptr.2072>. Accessed: Jun. 22, 2020. doi: 10.1002/ptr.2072.

EUROPEAN PHARMACOPOEIA COMMISSION. European Pharmacopoeia. European Pharmacopoeia Commission, 2007.

FAO. The State of World Fisheries and Aquaculture 2020. Sustainability in action. Rome. Available from: <https://doi. org/10.4060/ca9229en>. Accessed: Jun. 22, 2020. doi: doi. org/10.4060/ca9229en.

JIANG, S. et al. Anaesthetic effect of eugenol at different concentrations and temperatures on blank tiger shrimp (Penaeus monodon). Aquaculture Research. 2020. Available from: $<$ https:// doi.org/10.1111/are.14662>. Accessed: Jun. 22, 2020. doi: 10.1016/j.ijdevneu.2013.12.006.

HENRY, R.P. et al. Multiple functions of the crustacean gill: osmotic/ionic regulation, acid-base balance, ammonia excretion, and bioaccumulation of toxic metals. Frontiers in Physiology, v. 3, p. 431, 2012. Available from: <https://doi.org/10.3389/fphys.2012.00431>. Accessed: Jun. 22, 2020. doi: 10.3389/fphys.2012.00431.

KIZAK, V. et al. Anesthetic efficacy of Cymbopogon citratus essential oil as a herbal agent in two ornamental fish species. The Israeli Journal of Aquaculture - Bamidgeh, IJA_70.2018.1505, 8 p. 2018. Available from: <http://hdl.handle.net/10524/58319>. Accessed: Jun. 22, 2020. (Electronic publication).

LI, Y. et al. Influence of temperature and size on menthol anaesthesia in Chinese grass shrimp Palaemonetes sinensis (Sollaud, 1911). Aquaculture Research, v. 49, n. 6, p. 20912098, 2018a. Available from: <https://doi.org/10.1111/are.13568>. Accessed: Jun. 22, 2020. doi: 10.1111/are.13568.

LI, Y. et al. Anaesthetic effects of eugenol on grass shrimp (Palaemonetes sinensis) of different sizes at different concentrations and temperatures. Scientific Reports, v. 8, n. 1, p. 1-9, 2018 b. Available from: <https://doi.org/10.1038/s41598-018-28975-w>. Accessed: Jun. 22, 2020. doi: 10.1038/s41598-018-28975-w.

LIGHTNER, D.V. Virus diseases of farmed shrimp in the western hemisphere: a review. Journal of Invertebrate Pathology, v. 106, n. 1, p. 110-130, 2011. Available from: <https://doi.org/10.1016/j. jip.2010.09.012>. Accessed: Jun. 22, 2020. doi: 10.1016/j. jip.2010.09.012.

MATULOVIC, F.M.; OSHIRO, L.M.Y. Uso de óleos essenciais como anestésico para manejo de camarões marinhos Litopenaeus schmitti e Farfantepenaeus brasiliensis. Revista Acadêmica Ciência Animal, v. 14, p. 57-68, 2016. Available from: $<\mathrm{https} / / /$ doi.org/10.7213/academica.14.2016.06>. Accessed: Jun. 22, 2020. doi: 10.7213/academica.14.2016.06.

MERCIER, L. et al. Metabolic and immune responses in Pacific whiteleg shrimp Litopenaeus vannamei exposed to a repeated handling stress. Aquaculture, v. 258, N. 1-4, p. 633-640, 2006. Available from: <https://doi.org/10.1016/j. aquaculture.2006.04.036>. Accessed: Jun. 22, 2020. doi: 10.1016/j. aquaculture.2006.04.036.

NILSSON, O.G. et al. Acetylcholine release in the rat hippocampus as studied by microdialysis is dependent on axonal impulse flow and 
increases during behavioural activation. Neuroscience, v. 36, n. 2, p. 325-338, 1990. Available from: <https://doi.org/10.1016/03064522(90)90429-8>. Accessed: Jun. 22, 2020. doi: 10.1016/0306$4522(90) 90429-8$.

PALOMERA, M.A.A. et al. Evaluation of natural extracts with anesthetic properties in juveniles Macrobrachium tenellum. PanAmerican Journal of Aquatic Sciences, v. 11, n. 3, p. 251257, 2016. Available from: <https://panamjas.org/pdf artigos/ PANAMJAS_11(3)_251-257.pdf $>$. Accessed: Jun. 22, 2020. (Electronic publication).

PARODI, T.V. et al. The anesthetic efficacy of eugenol and the essential oils of Lippia alba and Aloysia triphylla in post-larvae and sub-adults of Litopenaeus vannamei (Crustacea, Penaeidae). Comparative Biochemistry and Physiology Part C, v. 155, n. 3, p. 462-468, 2012. Available from: <https://doi.org/10.1016/j.cbpc.2011.12.003>. Accessed: Jun. 22, 2020. doi: 10.1016/j.cbpc.2011.12.003.

PRETO, A.L. et al. Production of live bait-shrimp (Farfantepenaeus paulensis) in cages at varying stoking densities. Boletim do Instituto de Pesca, v. 35, p. 39-45, 2009. Available from: <https:// www.pesca.sp.gov.br/boletim/index.php/bip/article/view/836>. Accessed: Jun. 22, 2020.

REVERTER, M. et al. Use of plant extracts in fish aquaculture as an alternative to chemotherapy: current status and future perspectives. Aquaculture, v. 433, p. 50-61, 2014. Available from: $<$ https://doi.org/10.1016/j.aquaculture.2014.05.048>. Accessed: Jun. 22, 2020. doi: 10.1016/j.aquaculture.2014.05.048.

SAYDMOHAMMED, M.; PAL, A.K. Anesthetic effect of eugenol and menthol on handling stress in Macrobrachium rosenbergii.
Aquaculture, v. 298, n. 1-2, p. 162-167, 2009. Available from: $<$ https://doi.org/10.1016/j.aquaculture.2009.10.020>. Accessed: Jun. 22, 2020. doi: 10.1016/j.aquaculture.2009.10.020

SILVA, L. L. et al. Essential oil of Ocimum gratissimum L.: Anesthetic effects, mechanism of action and tolerance in silver catfish, Rhamdia quelen. Aquaculture, v. 350, p. 91-97, 2012. Available from: <http://dx.doi.org/10.1016/j. aquaculture.2012.04.012>. Accessed: Jun. 22, 2020. dx.doi:10.1016/j.aquaculture.2012.04.012.

SOUZA, C.F. et al. Nanoencapsulated Melaleuca alternifolia essential oil exerts anesthetic effects in the brachyuran crab using Neohelice granulate. Anais da Academia Brasileira de Ciências, v. 90, n. 3 , p. $2855-2864,2018$. Available from: $<$ https://doi. org/10.1590/0001-3765201820170930>. Accessed: Jun. 22, 2020. doi:10.1590/0001-3765201820170930.

SOUZA, C.F. et al. Essential oils as stress-reducing agents for fish aquaculture: A Review. Frontiers in Physiology, v. 10, p. 785, 2019. Available from: <https://doi.org/10.3389/fphys.2019.00785>. Accessed: Jun. 22, 2020. doi: 10.3389/fphys.2019.00785.

TAYLOR, J. et al. Minimizing the effects of stress during eyestalk ablation of Litopenaeus vannamei females with topical anesthetic and a coagulating agent. Aquaculture, v. 233, n. 1-4, p. 173-179, 2004. Available from: <https://doi.org/10.1016/j. aquaculture.2003.09.034>. Accessed: Jun. 22, 2020. doi: 10.1016/j. aquaculture.2003.09.034.

UNESCO. Chemical methods for use in marine environmental monitoring. Manual and Guides 12, Intergovernmental Oceanographic Commission, Paris. 1983. 